\title{
Assessment of antimicrobial activity of sodium hypochlorite, calcium hypochlorite and grape seed extract against Enterococcus faecalis
}

\author{
Larissa Taís Soligo ${ }^{a}$, Ezequiel Santin Gabriellib, Huriel Scartazzini Palhano ${ }^{a}$, Ana Paula Farina ${ }^{a}$, \\ Matheus Albino Souza ${ }^{a}$, Doglas Cecchin ${ }^{a}$
}

\begin{abstract}
OBJECTIVE: This study aimed to assess the antimicrobial action of calcium hypochlorite $\left[\mathrm{Ca}(\mathrm{OCl})_{2}\right]$ at concentrations of $2.5 \%$ and $6 \%$, and of grape seed extract (GSE) at concentrations of $10 \%, 30 \%$, and $50 \%$, against Enterococcus faecalis, comparing it to the action of $6 \%$ sodium hypochlorite $(\mathrm{NaOCI})$. METHODS: Saline solution was used as negative control. The inhibition halos of microbial growth were verified by the agar disk diffusion method. Twelve Petri plates were used for seeding with culture medium of approximately $5 \mathrm{~mm}$ in thickness. In each plate, 5 disks of pure and sterile antibiogram, soaked in the substances to be tested, were used and taken to the plate containing the seeded bacterial strain. The plates remained in aerobic bacteriological incubator for $24 \mathrm{~h}$ at $37^{\circ} \mathrm{C}$ temperature. After $24 \mathrm{~h}$, the inhibition halos were measured with a digital caliper. Analysis of Variance (ANOVA) was used for statistical analysis followed by Tukey's complementary test, at $5 \%$ significance. RESULTS: The $6 \% \mathrm{Ca}(\mathrm{ClO})_{2}$ presented inhibition halo statistically higher than the other solutions $(p<0.05)$, followed by $2.5 \% \mathrm{Ca}(\mathrm{ClO})_{2}$, which was statistically similar to $6 \% \mathrm{NaOCl}(p>0.05)$. The GSE concentrations resulted in lower inhibition halos of active substances and the different concentrations were similar to each other. Lastly, saline solution presented the same inhibition halos in all groups $(\mathrm{p}<0.05)$

CONCLUSION: It may be concluded that $6 \% \mathrm{Ca}(\mathrm{OCl})_{2}$ presented higher antimicrobial activity than $6 \% \mathrm{NaOCl}$. On the other hand, all GSE concentrations were lower than $\mathrm{NaOCl}$ and $\mathrm{Ca}(\mathrm{OCl})_{2}$.

Keywords: calcium hypochlorite; sodium hypochlorite; grape seed extract; Enterococcus faecalis.
\end{abstract}

\section{Avaliação da atividade antimicrobiana do hipoclorito de sódio, hipoclorito de cálcio e do extrato de semente de uva contra o Enterococcus faecalis}

\section{RESUMO}

OBJETIVO: O objetivo deste estudo foi avaliar a atividade antimicrobiana do hipoclorito de cálico $\left[\mathrm{Ca}(\mathrm{OCl})_{2}\right]$ nas concentrações de $2,5 \%$ e $6 \%$ e do extrato de semente de uva (GSE) nas concentrações de $10 \%, 30 \%$ e $50 \%$ contra o Enterococcus faecalis, e comparar com a atividade do hipoclorito de sódio a 6\% (NaOCl).

MÉTODOS: Soro fisiológico foi utilizado como grupo controle. Os halos de inibição do crescimento microbiano foram verificados pelo método de Difusão em Ágar. Foram utilizadas doze placas de Petri para semeadura com meio de cultura apresentando aproximadamente $5 \mathrm{~mm}$ de espessura. Foram utilizados em cada placa 5 discos de antibiograma puro e estéril embebidos nas substâncias a serem testadas e levados até a placa contendo a cepa bacteriana semeada. As placas permaneceram em estufa bacteriológica aeróbia durante $24 \mathrm{~h}$ numa temperatura de $37^{\circ} \mathrm{C}$. Após $24 \mathrm{~h}$, os halos de inibição foram mensurados com parquímetro digital. Para análise estatística utilizou-se ANOVA seguido pelo teste complementar de Tukey à $5 \%$ de significanica.

RESULTADOS: $\mathrm{Ca}(\mathrm{ClO})_{2} 6 \%$ apresentou halo de inibição estatisticamente maior que as demais soluções $(p<0.05)$, seguido do $\mathrm{Ca}(\mathrm{ClO})_{2} 2,5 \%$ que foi semelhante estatisticamente ao $\mathrm{NaOCl} 6 \%(p>0,05)$. As concentrações de GSE resultaram nos menores halos de inibição substâncias ativas e as diferentes concentrações foram semelhantes entre si. Por fim, o soro fisiológico apresentou os menos halos de inibição entre todos os grupos $(p<0,05)$. CONCLUSÃO: Pode-se concluir que o $\mathrm{Ca}(\mathrm{OCl})_{2} 6 \%$ apresentou atividade antimicrobiana superior ao $\mathrm{NaOCl} 6 \%$, por outro lado todas as concentrações de GSE foram inferiores ao $\mathrm{NaOCl}$ e ao $\mathrm{Ca}(\mathrm{OCl})_{2}$.

Palavras-chave: hipoclorito de cálico; hipoclorito de sódio; extrato de semente de uva; Enterococcus faecalis. a Post-Graduation Program in Dentistry, School of Dentistry, University of Passo Fundo, Brazil

${ }^{b}$ Post-Graduation Program in Dental Clinic, School of Dentistry, State University of Campinas, Brazi

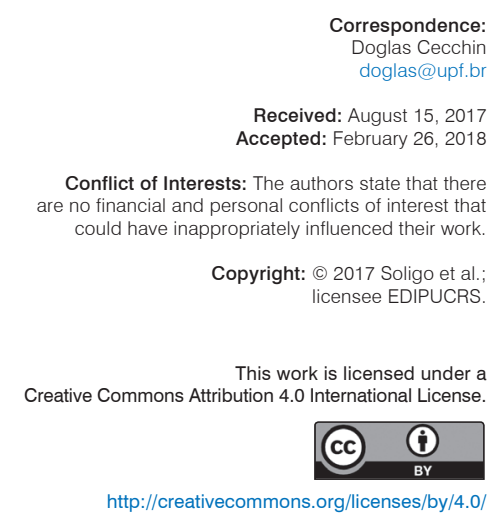

http://creativecommons.org/licenses/by/4.0/ 


\section{INTRODUCTION}

Enterococcus faecalis (E. faecalis) is a strong bacterium with ability to survive in root canals as a single organism. It can invade dentinal tubules and resist the action of antimicrobial substances. Because of these features, it is the main microorganism related to endodontic failure $[1,2]$. In order to eliminate microorganisms, the cleaning and disinfection of root canals depend on the both action of endodontic instruments and the chemical action of auxiliary substances. The use of endodontic instruments considerably reduces the number of microorganisms within the root canal; however, it is not enough to provide adequate disinfection, so requiring the use of auxiliary chemical substances [3].

The most used solution in Endodontics is sodium hypochlorite $(\mathrm{NaOCl})$, which main component is chloride. In contact with dentin, the $\mathrm{NaOCl}$ is dissociated into sodium hydroxide and hypochlorous acid, which are responsible for the ability of tissue dissolution and antimicrobial activity of this solution, respectively [4]. However, it presents cytotoxicity and intense irritation when extrusion occurs through the apical foramen $[4,5]$. Moreover, it promotes dentin collagen degeneration $[6,7]$ and, consequently, negatively interferes with the adhesion of restorative materials to dentin $[8,9]$.

Considering the disadvantages of $\mathrm{NaOCl}$, it is important to study new auxiliary chemical solutions that may be used during root canal preparation. Calcium Hypochlorite $\left[\mathrm{Ca}(\mathrm{ClO})_{2}\right]$ is a white granulate extensively used in water treatment and as a bleaching agent [10]. It is considered chemically stable and has more chloride available than $\mathrm{NaOCl}$ [11]. Moreover, its ability to dissolve organic matter [10] and its antimicrobial activity against $E$. faecalis [11] have been reported with acceptable cytotoxicity and biocompatibility [13].

Another substance that indicated antimicrobial activity in Endodontics and advances for Restorative Dentistry was Grape Seed Extract (GSE), which is a substance richly composed of PAs (proanthocyanidins) [14] from plants such as stems, fruits, seeds, and flowers [15]. Grape Seed Extract induces crosslinking in dentin collagen [16] and it presents low cytotoxicity [17]. It is believed that GSE presents satisfactory antimicrobial activity, considering that Cecchin et al. [18] observed that it presents good ability to eliminate E. faecalis when used in straight canals with manual instruments.

Considering the above, the present study aimed to assess bacterial growth inhibition caused by different auxiliary chemical solutions $\left(\mathrm{GSE}, \mathrm{Ca}(\mathrm{ClO})_{2}\right.$, and $\left.\mathrm{NaOCl}\right)$ against E. faecalis through the inhibition halo test. The hypothesis tested was that different auxiliary chemical substances would have the same antimicrobial activity.

\section{MATERIALS AND METHODS}

\section{Study design}

The present work is an experimental laboratory study proposed to determine the antimicrobial activity of the following auxiliary chemical substances: 10\% GSE (MegaNatural, Madera, CA, USA), 30\% GSE, and 50\% GSE; $6 \% \mathrm{NaOCl}$ (Natupharma, Passo Fundo, RS, Brazil); and $2.5 \% \mathrm{Ca}(\mathrm{ClO})_{2}$ (Lírios, São Vicente, SP, Brazil) and 6\% $\mathrm{Ca}(\mathrm{ClO})_{2}$. All substances were tested against E. faecalis (American Type Culture Collection 19433) by delimiting inhibition halos through the agar disk diffusion method. The disks used were white for pure antibiogram (no antibiotics) and sterilized by autoclaving (Laborclin Produtos para Laboratórios Ltda., Pinhais, PR, Brazil).

\section{Preparation of substances}

The $6 \%$ concentration of $\mathrm{NaOCl}$ was prepared by the compounding pharmacy Natupharma, Passo Fundo, RS, Brazil.

The $10 \%, 30 \%$, and $50 \%$ concentrations of GSE (Mega-Natural, Madera, CA, USA) and the 2.5\% and $6 \%$ concentrations of $\mathrm{Ca}(\mathrm{ClO})_{2}$ (Lírios, São Vicente, SP, Brazil) were prepared from their respective granules. The raw material of substances was diluted in distilled water, resulting in the desired concentrations at the Chemistry Laboratory of the University of Passo Fundo. Different concentrations were prepared at weight/volume ratio and mixed with a magnetic stirrer for 10 minutes.

\section{Preparation of the Inoculum}

The E. faecalis strain (ATCC 19433) was reactivated in Brain Heart Infusion broth (BHI, Difco, Kansas City, MO, USA) and incubated at $37^{\circ} \mathrm{C}$ for 24 hours. Next, it was transferred to a new tube containing BHI broth and incubated for 24 hours more under the same conditions; medium density was adjusted in a spectrophotometer, equivalent to 1.0 in the McFarland scale $\left(3 \times 10^{8} \mathrm{CFU} \mathrm{mL}-1\right)$. After adjusting bacterial concentration, the inoculum was incubated once again at $37^{\circ} \mathrm{C}$ for 7 hours, to reach exponential growth.

\section{Plate Seeding}

Twelve 90-mm Petri plates were used for seeding $(\mathrm{n}=10)$. The culture medium of the plates was Agar Mueller Hinton, with approximately $5 \mathrm{~mm}$ in thickness. Five disks were used in each plate.

For assistance, a swab was immersed in the BHI inoculum containing the bacterial strain and pressed on the tube walls to remove the excess. Seeding was performed in four different orientations and around the edge of the plate, in order to ensure that the entire medium was seeded.

\section{Application of Disks}

The disks remained in the refrigerator up to $2 \mathrm{~h}$ before use. Right after seeding, there was a 5-minute interval for the medium to dry at room temperature and to absorb the inoculum before applying the disks.

Each substance tested remained in a sterile Eppendorf tube until use. After 5 minutes, aided by clinical tweezers for sterile cotton (Colgran, São Caetano do Sul, SP, Brazil), the antibiogram disk was previously soaked in the substance for 10 minutes, removed and waited 30 s to be placed on the plate. 
When disk placement was finished, the plate was closed and maintained in aerobic bacteriological incubator for $24 \mathrm{~h}$ at $37^{\circ} \mathrm{C}$ temperature. In the first 15 minutes, the plates remained incubated in reverse so the disks would not move, then they were turned with the lid down to prevent the accumulation of droplets on the lid, interfering with the culture medium.

\section{Microbiological Assessment}

After $24 \mathrm{~h}$, the plates were removed from the incubator and the inhibition halos from the substances were measured, aided by a digital caliper (Vonder Paquímetro Eletrônico Digital, Curitiba, PR, Brazil).

All plates were read with the help of a light source. The halos were considered from the point where no bacterial growth was visible to the naked eye.

\section{Statistical analysis}

The statistical analysis used was ANOVA followed by Tukey's complementary test, for group comparison, at 5\% significance level. For results analysis, the software Stat Plus Analyst Soft Inc. version 6.0 (Vancouver, BC, Canada) was used.

\section{RESULTS}

The statistical analysis showed statistically significant difference among groups $(\alpha=0.05)$. The $6 \% \mathrm{Ca}(\mathrm{ClO})_{2}$ presented inhibition halo statistically higher than the other solutions ( $\mathrm{p}<0.05$ ), followed by $2.5 \% \mathrm{Ca}(\mathrm{ClO})_{2}$, which was statistically similar to $6 \% \mathrm{NaOCl}(\mathrm{p}>0.05)$, as described in Table 1.

Table 1. Reduction of Enterococcus faecalis by the agar disk diffusion technique through the direct contact method $(n=10)$.

\begin{tabular}{lcc}
\hline $\begin{array}{c}\text { Auxiliary Chemical } \\
\text { Solutions }\end{array}$ & $\begin{array}{c}\text { Inhibition Halos } \\
\text { (Mean } \pm \text { Standard Deviation) }\end{array}$ & $\begin{array}{c}\text { Tukey's Statistical } \\
\text { Test }\end{array}$ \\
Saline solution & $0.00 \pm 0.00$ & $\mathrm{D}$ \\
$10 \% \mathrm{GSE}$ & $10.40 \pm 1.16$ & $\mathrm{C}$ \\
$30 \% \mathrm{GSE}$ & $11.97 \pm 0.48$ & $\mathrm{C}$ \\
$50 \% \mathrm{GSE}$ & $13.07 \pm 0.65$ & $\mathrm{C}$ \\
$6 \% \mathrm{NaOCl}$ & $18.52 \pm 1.37$ & $\mathrm{~B}$ \\
$2.5 \% \mathrm{Ca}(\mathrm{ClO})_{2}$ & $22.34 \pm 4.96$ & $\mathrm{~B}$ \\
$6 \% \mathrm{Ca}(\mathrm{ClO})_{2}$ & $29.82 \pm 8.23$ & $\mathrm{~A}$ \\
\hline
\end{tabular}

Data are presented as mean \pm standard deviation. The $p$ values are significant using the analysis of variance in the columns. Different letters represent statistically significant differences in the post-hoc procedure (Tukey's test). GSE, Grape Seed Extract; NaOCl Sodium Hypochlorite; $\mathrm{Ca}(\mathrm{ClO})_{2}$, Calcium Hypochlorite.

The $10 \%, 30 \%$, and $50 \%$ concentrations of GSE showed reduced antimicrobial effectiveness when compared to $\mathrm{Ca}(\mathrm{ClO})_{2}$ and $\mathrm{NaOCl}$. All GSE concentrations resulted in the lowest inhibition halos among the active substances. Lastly, saline solution, considered as control group, presented lower and different results from the other groups $(\mathrm{p}<0.05)$.

\section{DISCUSSION}

The methodology applied in this research adopted the analysis of the size of bacterial growth display areas, in agar diffusion. It is possible to verify that the $6 \% \mathrm{Ca}(\mathrm{ClO})_{2}$ solution was the concentration that presented the highest inhibition halo. On the other hand, $2.5 \% \mathrm{Ca}(\mathrm{ClO})_{2}$ and $6 \%$ $\mathrm{NaOCl}$ presented lower halos, but similar to each other. These results show that $2.5 \% \mathrm{Ca}(\mathrm{ClO})_{2}$ presents adequate capacity of bacterial inhibition when compared to high concentrations of $\mathrm{NaOCl}$, considering that some studies prove the efficiency of $\mathrm{NaOCl}$ at different concentrations $[4,12]$. From these results, the hypothesis under analysis was rejected. There are few studies on $\mathrm{Ca}(\mathrm{ClO})_{2}$ in the field of Endodontics. This substance was introduced for favoring organic matter degradation at the same proportion of $\mathrm{NaOCl}$ and for being more stable [12]. The $\mathrm{Ca}(\mathrm{ClO})_{2}$ is an alkaline solution with higher chloride content available than $\mathrm{NaOCl}$ [11], produced by the dissolution of chlorine gas $\left(\mathrm{Cl}_{2}\right)$ in a solution of calcium oxide $(\mathrm{CaO})$ and sodium hydroxide $(\mathrm{NaOH})$, which when diluted in water turns into hypochlorous acid $[10,19]$. Its antimicrobial activity may be justified by the high amount of chloride available. High doses of hypochlorous acid are released and invade the bacterial cell wall, destroying the microorganisms present in infections [12]. Using an antimicrobial assessment method different from this study, De-Almeida et al. [12] and Dumani et al. [20] assessed the antimicrobial capacity of $\mathrm{Ca}(\mathrm{ClO})_{2}$ and proved its effectiveness, considering the solution was able to reduce CFUs without statistical differences with the group using $\mathrm{NaOCl}$.

The antimicrobial efficacy of $\mathrm{NaOCl}$ has been extensively discussed in the literature $[21,22]$. The $\mathrm{NaOCl}$ consists of sodium salts of hypochlorous acid and it is a compound that contains chloride, which may be used as disinfectant [23]. The $\mathrm{NaOCl}$ solution presents a high and stable $\mathrm{pH}$, slowly releasing chloride [24]. However, its efficacy may be affected by concentration, temperature, and $\mathrm{pH}[25,26]$. When the $\mathrm{pH}$ is low, the free chloride of $\mathrm{NaOCl}$ joins the hypochlorous acid $(\mathrm{HOCl})$, which is more active than hypochlorite anion (OCl) [24].

The GSE was the active solution tested that presented the lowest inhibition halo, therefore with lower antimicrobial activity than Hypochlorite solutions. The interest for this substance is based on antibacterial, antifungal, antiviral, antioxidant, anti-inflammatory, and analgesic properties [17, 27]. The structure of GSE presents PAs [14], which improves the mechanical properties of dentin collagen [16] with proved antimicrobial activity [18]. The phenolic contents present in grape seeds are relatively hydrophobic and communicate with the bacterial cell wall, decreasing membrane stability. Up to now, there are few studies on GSE for endodontic use, and because it is a phytotherapeutic substance, it requires additional studies to prove its effectiveness, provided there is no consensus on the proper concentration for the solution, which does not allow objective conclusions on its use. Studies on the antimicrobial activity 
of GSE in Endodontics are scarce in the literature. Baydar et al. [28] tested GSE at concentrations of 1\%, 2.5\%, 5\%, and $10 \%$ for several bacteria, E. faecalis among them, by the agar diffusion method, analyzing inhibition halos. The authors concluded that all concentrations were effective for the bacteria tested. In this study, GSE presented the lowest bacterial reduction from the other solutions, even at a higher concentration of $50 \%$. The GSE may be used as an option of irrigating solution in Endodontics, because it does not interfere with dentin collagen, preserving the quality of dentin substrate in order to obtain an adequate root canal sealing at the moment of filling and, later, for composite resin restoration. Moreover, teeth are an interesting option for the preparation of thin roots or incomplete rhizogenesis, due to low cytotoxicity [17] and their positive properties on dentin collagen $[16,29]$. It is important to report that, for $\mathrm{Ca}(\mathrm{ClO})_{2}$ and $\mathrm{GSE}$ solutions, the formation of a precipitate was observed, in which the solid portion was deposited at the bottom of the solution flask. For the solution not to lose its concentration, the flask must be agitated for better diluting the solid portion with the liquid one at the moment of use.

The $\mathrm{Ca}(\mathrm{ClO})_{2}$ presented favorable result regarding its antimicrobial activity. In vivo researches should be performed to verify the effectiveness of $\mathrm{Ca}(\mathrm{ClO})_{2}$ and $\mathrm{GSE}$ as auxiliary chemical solutions for endodontic treatment.

\section{CONCLUSIONS}

After the results obtained in this study, it may be concluded that the highest antimicrobial activity was presented by $6 \%$ $\mathrm{Ca}(\mathrm{ClO})_{2}$ followed by $2.5 \% \mathrm{Ca}(\mathrm{ClO})_{2}$, which was similar to $6 \% \mathrm{NaOCl}$. The different GSE concentrations did not present statistically significant differences and presented lower antimicrobial capacity than the other substances tested.

\section{REFERENCES}

1. Stuart $\mathrm{CH}$, Schwartz SA, Beeson TJ, Owatz CB. Enterococcus faecalis: its role in root canal treatment failure and current concepts in retreatment. J Endod. 2006;32:93-8. http://dx.doi.org/10.1016/j.joen.2005.10.049

2. Sundqvist G, Figdor D. Life as an endodontic pathogen. Ecological differences between the untreated and root-filled root canals. Endod Topics. 2003;6:3-28

3. Byström A, Sundqvist G. Bacteriologic evaluation of the efficacy of mechanical root canal instrumentation in endodontic therapy. Scand $J$ Dent Res. 1981;89:321-8.

4. Zehnder M. Root canal irrigants. J Endod. 2006;32:389-98

5. Motta MV, Chaves-Mendonca MA, Stirton CG, Cardozo HF. Accidental injection with sodium hypochlorite: report of a case. Int Endod J. 2009;42:175-82. http://dx.doi.org/10.1111/j.1365-2591.2008.01493.x

6. Moreira DM, Almeida JF, Ferraz CC, Gomes BP, Line SR, Zaia AA Structural analysis of bovine root dentin after use of different endodontics auxiliary chemical substances. J Endod. 2009;35:1023-7. http://dx.doi. org/10.1016/j.joen.2009.04.002

7. Ghisi AC, Kopper PM, Baldasso FE, Stürmer CP, Rossi-Fedele G, Steier L, de Figueiredo JA, Morgental RD, Vier-Pelisser FV. Effect of superoxidized water and sodium hypochlorite, associated or not with EDTA, on organic and inorganic components of bovine root dentin. J Endod. 2015;41: 925-30. http://dx.doi.org/10.1016/j.joen.2015.01.039

8. Santos JN, Carrilho MR, De Goes MF, Zaia AA, Gomes BP, Souza-Filho FJ, Ferraz CC. Effect of chemical irrigants on the bond strength of a selfetching adhesive to pulp chamber dentin. J Endod. 2006;32:1088-90. http://dx.doi.org/10.1016/j.joen.2006.07.001
9. Farina AP, Cecchin D, Barbizam JV, Carlini-Júnior B. Influence of endodontic irrigants on bond strength of a self-etching adhesive. Aust Endod $\mathrm{J}$. 2011;37:26-30. http://dx.doi.org/10.1111/j.1747-4477.2010.00249.x

10. Dutta A, Saunders WP. Comparative evaluation of calcium hypochlorite and sodium hypochlorite on soft-tissue dissolution. J Endod. 2012;38:1395-8. http://dx.doi.org/10.1016/j.joen.2012.06.020

11. Leonardo NG, Carlotto IB, Luisi SB, Kopper PM, Grecca FS, Montagner F Calcium Hypochlorite Solutions: Evaluation of Surface Tension and Effect of Different Storage Conditions and Time Periods over $\mathrm{pH}$ and Available Chlorine Content. J Endod. 2016;42:641-5. http://dx.doi.org/10.1016/j. joen.2016.01.006

12. de Almeida AP, Souza MA, Miyagaki DC, Dal Bello Y, Cecchin D, Farina AP. Comparative evaluation of calcium hypochlorite and sodium hypochlorite associated with passive ultrasonic irrigation on antimicrobial activity of a root canal system infected with Enterococcus faecalis: an in vitro study. J Endod. 2014;40:1953-7. http://dx. doi.org/10.1016/j.joen.2014.08.025

13. Blattes GB, Mestieri LB, Böttcher DE, Fossati AC, Montagner F, Grecca FS. Cell migration, viability and tissue reaction of calcium hypochlorite based-solutions irrigants: An in vitro and in vivo study. Arch Oral Biol. 2017;73:34-39. http://dx.doi.org/10.1016/j.archoralbio.2016.08.037

14. Wu CD. Grape products and oral health. J Nutr 2009;139:1818S-23S. http://dx.doi.org/10.3945/jn.109.107854

15. Sarni-Manchado P, Cheynier V, Moutounet M. Interactions of grape seed tannins with salivary proteins. J Agric Food Chem. 1999:47:42-7. http:// dx.doi.org/10.1021/jf9805146

16. Al-Ammar A, Drummond JL, Bedran-Russo AK. The use of collagen crosslinking agents to enhance dentin bond strength. J Biomed Mater Res B Appl Biomater. 2009;91:419-24.http://dx.doi.org/10.1002/jbm.b.31417

17. Bagchi D, Bagchi M, Stohs SJ, Das DK, Ray SD, Kuszynski CA, Josh SS, Pruess HG. Free radicals and grape seed proanthocyanidin extract: importance in human health and disease prevention. Toxicology. 2000;148:187-97. https://doi.org/10.1016/S0300-483X(00)00210-9

18. Cecchin D, Farina AP, Souza MA, Albarello LL, Schneider AP, Vidal CM Bedran-Russo AK. Evaluation of antimicrobial effectiveness and dentine mechanical properties after use of chemical and natural auxiliary irrigants. J Dent. 2015;43:695-702. doi: 10.1016/j.jdent.2015.03.013.

19. Su YS, Morrison DT, Ogle RA. Chemical kinetics of calcium hypochlorite decomposition in aqueous solution. Chem Health Saf. 2009;16:21-5. http://dx.doi.org/10.1016/j.jchas.2008.07.002

20. Dumani A, Guvenmez HK, Yilmaz S, Yoldas O, Kurklu ZG.Antibacterial Efficacy of Calcium Hypochlorite with Vibringe Sonic Irrigation System on Enterococcus faecalis: An In Vitro Study. Biomed Res Int. 2016:8076131. http://dx.doi.org/10.1155/2016/8076131

21. Baumgartner JC, Cuenin PR. Efficacy of several concentrations of sodium hypochlorite for root canal irrigation. J Endod. 1992;18:605-12. http:// dx.doi.org/10.1016/S0099-2399(06)81331-2

22. Vianna ME, Gomes BP, Berber VB, Zaia AA, Ferraz CC, de Souza-Filho FJ. In vitro evaluation of the antimicrobial activity of chlorhexidine and sodium hypochlorite. Oral Surg Oral Med Oral Pathol Oral Radiol Endod. 2004;97:79-84. http://dx.doi.org/10.1016/S1079-2104(03)00360-3

23. Whittaker HA, Mohler BM.The Sterilization of Milk Bottles With Calcium Hypochlorite. Am J Public Health (NY)1912;2:282-7.

24. Dornelles-Morgental R, Guerreiro-Tanomaru JM, de Faria-Júnior NB Hungaro-Duarte MA, Kuga MC, Tanomaru-Filho M. Antibacterial efficacy of endodontic irrigating solutions and their combinations in root canals contaminated with Enterococcus faecalis. Oral Surg Oral Med Oral Pathol Oral Radiol Endod. 2011;112:396-400. http://dx.doi.org/10.1016/i. tripleo.2011.02.004

25. Camps J, Pommel L, Aubut V, Verhille B, Satoshi F, Lascola B, About I. Shelf life, dissolving action, and antibacterial activity of a neutralized $2.5 \%$ sodium hypochlorite solution. Oral Surg Oral Med Oral Pathol Oral Radiol Endod. 2009;108:e66-73. http://dx.doi.org/10.1016/j.tripleo.2009.03.034

26. Mercade M, Duran-Sindreu F, Kuttler S, Roig M, Durany N. Antimicrobial efficacy of $4.2 \%$ sodium hypochlorite adjusted to $\mathrm{pH} 12,7.5$, and 6.5 in infected human root canals. Oral Surg Oral Med Oral Pathol Oral Radiol Endod. 2009;107:295-8. http://dx.doi.org/10.1016/j.tripleo.2008.05.006

27. Saito M, Hosoyama H, Ariga T, Kataoka S, Yamaji N. Antiulcer activity of grape seed extract and procyanidins. J Agric Food Chem 1998;46:1460-4.

28. Baydar NG, Sagdic O, Ozkan G, Cetin S. Determination of antibacteria effects and total phenolic contents of grape (Vitis vinifera L.) seed extracts. Int J Food SCI Tech 2006;41:799-804.

29. Vidal CM, Aguiar TR, Phansalkar R, McAlpine JB, Napolitano JG, Chen SN, Araújo LS, Pauli GF, Bedran-Russo A. Galloyl moieties enhance the dentin biomodification potential of plant-derived catechins. Acta Biomater. 2014; 10:3288-94. doi: 10.1016/j.actbio.2014.03.036 